Chapter 13

\title{
Advantages and Disadvantages of pXRF for Archaeological Ceramic Analysis: Prehistoric Pottery Distribution and Trade in NW Florida
}

\author{
R. H. Tykot," N. M. White, J. P. Du Vernay, J. S. Freeman, C. T. Hays, \\ M. Koppe, C. N. Hunt, R. A. Weinstein, and D. S. Woodward \\ Department of Anthropology, University of South Florida, \\ Tampa, Florida 33620, U.S.A. \\ *E-mail: rtykot@usf.edu
}

\begin{abstract}
Ceramic artifacts from northwest Florida were tested non-destructively with a portable X-ray fluorescence spectrometer to study production and trade during the Late Archaic, Late Prehistoric, and Protohistoric periods. Analyses using a Bruker III-V were conducted on 500 ceramic samples from 8 archaeological sites, for 180 seconds and using a filter that provides highly precise data for trace elements $\mathrm{Rb}, \mathrm{Sr}, \mathrm{Y}$, $\mathrm{Zr}$, and $\mathrm{Nb}$. While these ceramics were not painted or glazed, analyses were done on both inside and outside surfaces, and on broken edges. Quantitative values in ppm were produced using widely shared calibration software for these elements, and principal components analysis of the data show that the ceramics fall into distinguishable site groups, with most of the artifacts tested most likely coming from clay sources near each site. Further investigation assesses whether there are patterns based on object type and decoration, and the advantages and disadvantages of using this method.
\end{abstract}

(C) 2013 American Chemical Society

In Archaeological Chemistry VIII; Armitage, R., et al.;

ACS Symposium Series; American Chemical Society: Washington, DC, 2013. 


\section{Introduction}

Sherds of pottery and other ceramics are often the most common artifacts found at archaeological sites, and their study is the basis for many interpretations about the pre-modern cultures that created and used them. The major questions addressed by studies of ceramics include (1) the technology used for their formation and firing (use of temper, slip, paint; pits or kilns; temperature and air control); (2) the socioeconomic circumstances in which they were produced (household, village, region, and involvement of specialists); (3) their purpose and actual usage; and (4) their distribution thru trade or exchange, ritual gifting, burial offerings, and other circumstances. In this study we specifically focus on the production and distribution of ceramics from archaeological sites in northwestern Florida by using a portable, non-destructive X-ray fluorescence spectrometer to perform the elemental analyses, while assessing its advantages and disadvantages relative to other instrumentation.

\section{Ceramics Tested}

Ceramic production began in the southeastern United States in the Late Archaic period, ca. 3000-1000 BC, and native American production continued at least through the $17^{\text {th }}$ century AD (Table I). The ceramics tested in this study were selected to represent the different time periods involved, and as much as possible to have statistically significant numbers of samples from each archaeological site (Table II).

Assemblages were selected from eight archaeological sites in the panhandle region of Florida, specifically along the Apalachicola River (Figure 1). Some of these sites have been excavated, some surveyed, and some are collections from local residents $(1-3)$.

At present, there are no formally published articles on elemental analysis of pottery in Florida, and fairly few in the Southeast overall (4). In this study, large numbers of pottery samples were selected from these eight sites for analysis. Most of the ceramics represented are everyday ware, although many have decorations (Figures 2, 3). A number of clay balls, known as Poverty Point Objects (PPO), from the Choctawhatchee Bay area were tested and compared with results obtained in a previous study on Tick Island in northeastern Florida and the actual site of Poverty Point in Louisiana (5) (Figures 4, 5). 
Table I. Chronology for northwest Florida and the sites tested in this study

\begin{tabular}{|c|c|c|}
\hline Time Period & Culture & Sites \\
\hline $10,000-7000 \mathrm{BC}$ & Paleoindian & \\
\hline $7000-3000 \mathrm{BC}$ & Early and Middle Archaic & \\
\hline $3000-1000 \mathrm{BC}$ & Late Archaic & $\begin{array}{l}\text { Choctawhatchee Bay sites, } \\
\text { Clark Creek, Louisiana sites } \\
\text { Poverty Point and Claiborne }\end{array}$ \\
\hline $1000 \mathrm{BC}-\mathrm{AD} 100$ & Deptford (Early Woodland) & Depot Creek \\
\hline $100-700 \mathrm{AD}$ & $\begin{array}{l}\text { Swift Creek (Early-Middle } \\
\text { Woodland) }\end{array}$ & Depot Creek; Otis Hare \\
\hline $400-700 \mathrm{AD}$ & $\begin{array}{l}\text { Early Weeden Island (Middle } \\
\text { Woodland) }\end{array}$ & Otis Hare \\
\hline $700-1000 \mathrm{AD}$ & $\begin{array}{l}\text { Late Weeden Island (Late } \\
\text { Woodland) }\end{array}$ & Otis Hare \\
\hline $1000-1700 \mathrm{AD}$ & $\begin{array}{l}\text { Fort Walton (Mississippian to } \\
\text { early historic) }\end{array}$ & $\begin{array}{l}\text { Curlee, Dove Point, } \\
\text { Richardson's Hammock, } \\
\text { Yon Mound }\end{array}$ \\
\hline $1600 ?-1750 ?$ & Lamar (early historic Indian) & Dove Point \\
\hline
\end{tabular}

Table II. Sample selection from eight sites in northern Florida

\begin{tabular}{|l|l|l|}
\hline Site & Site Number & Samples Tested \\
\hline Choctawhatchee Bay & $8 \mathrm{Ok} 51 / 54 / 62 /$ other & 40 \\
\hline Clark Creek & $8 \mathrm{Gu} 60$ & 1 \\
\hline Curlee & $8 \mathrm{Ja} 7$ & 167 \\
\hline Depot Creek & $8 \mathrm{Gu} 56$ & 41 \\
\hline Dove Point & $8 \mathrm{Fr} 79$ & 135 \\
\hline Otis Hare & $8 \mathrm{Li} 172$ & 35 \\
\hline Richardson's Hammock & $8 \mathrm{Gu} 10$ & 6 \\
\hline Yon Mound & $8 \mathrm{Li} 2$ & 83 \\
\hline & Total & 508 \\
\hline
\end{tabular}




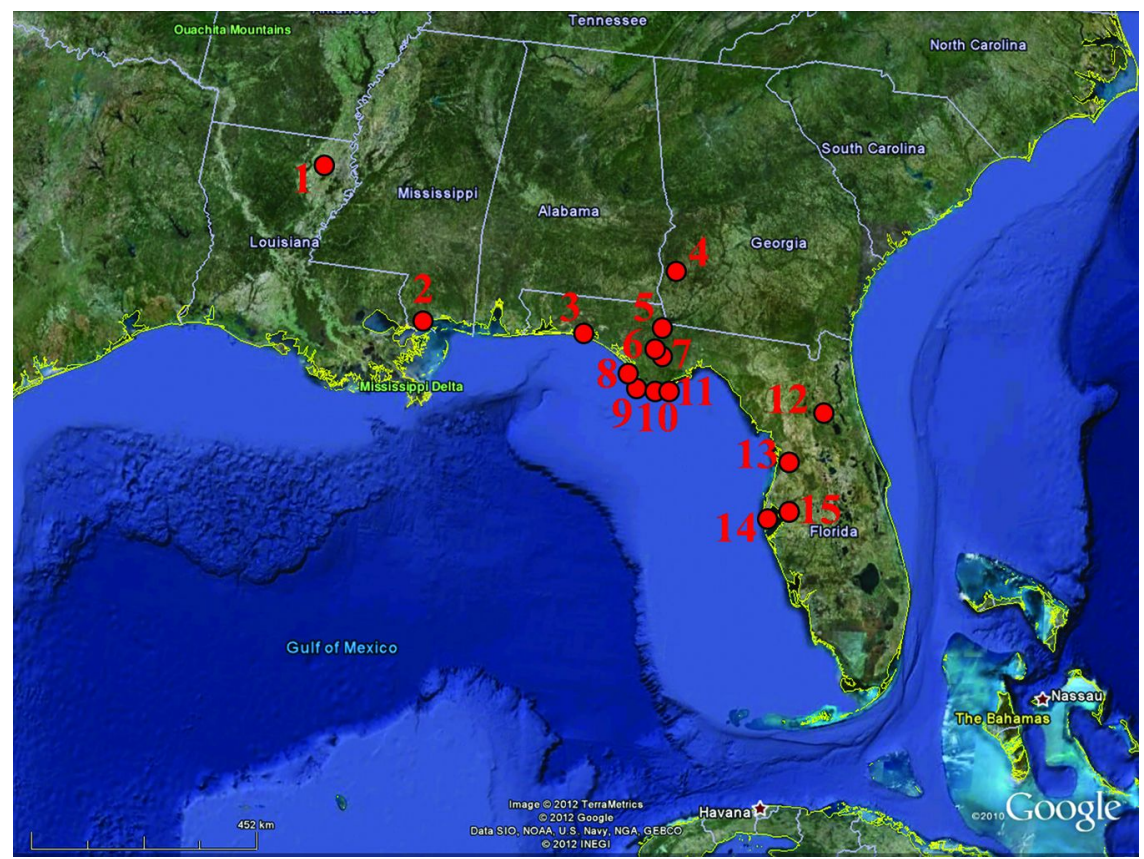

Figure 1. Map of southeastern US showing archaeological sites tested: 1. Poverty Point; 2. Claiborne; 3. Choctawhatchee Bay; 4. Kolomoki; 5. Curlee; 6. Yon Mound; 7. Otis Hare; 8. Clark Creek; 9. Richardson's Hammock; 10. Depot Creek; 11. Dove Point; 12. Tick Island; 13. Crystal River; 14. Bayshore Homes; 15. Jones Mound. 

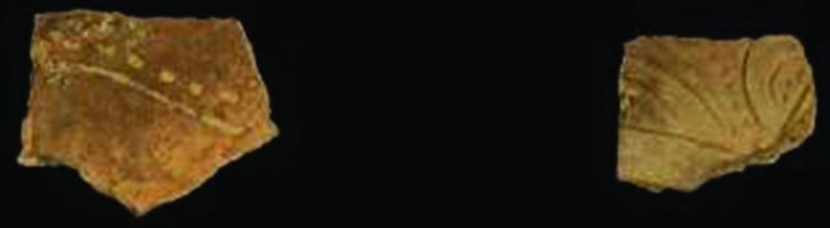

$\mathrm{Cr}$

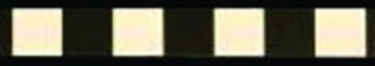

CN
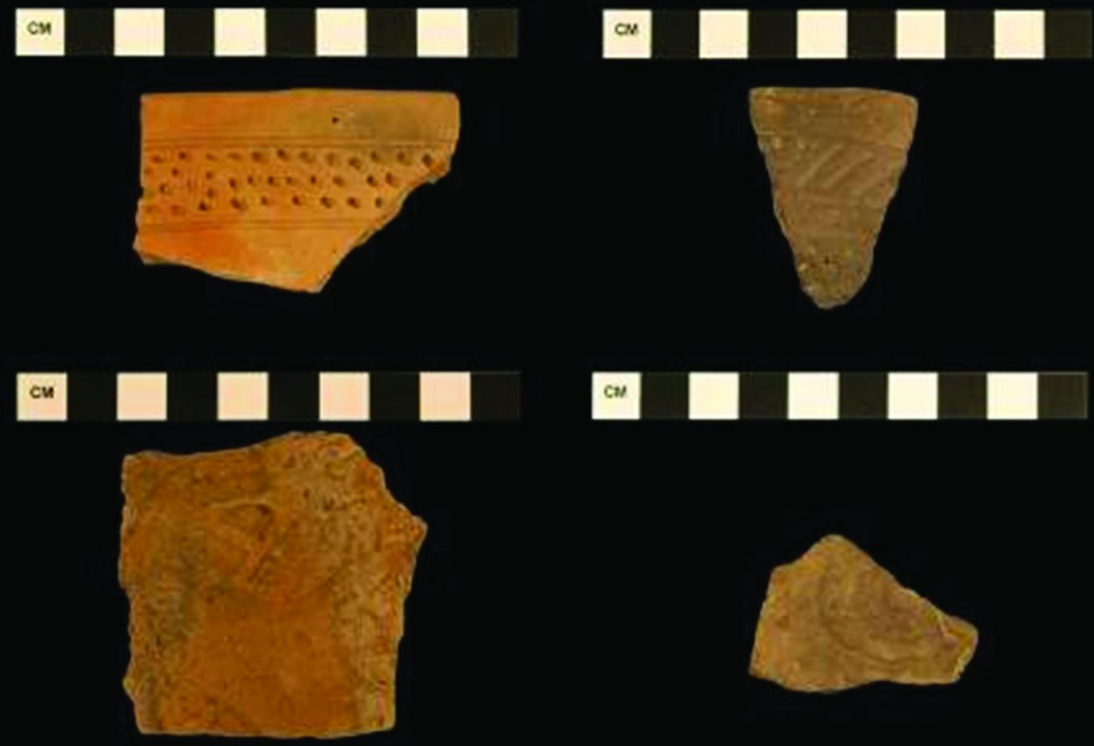

$\mathrm{cu}$
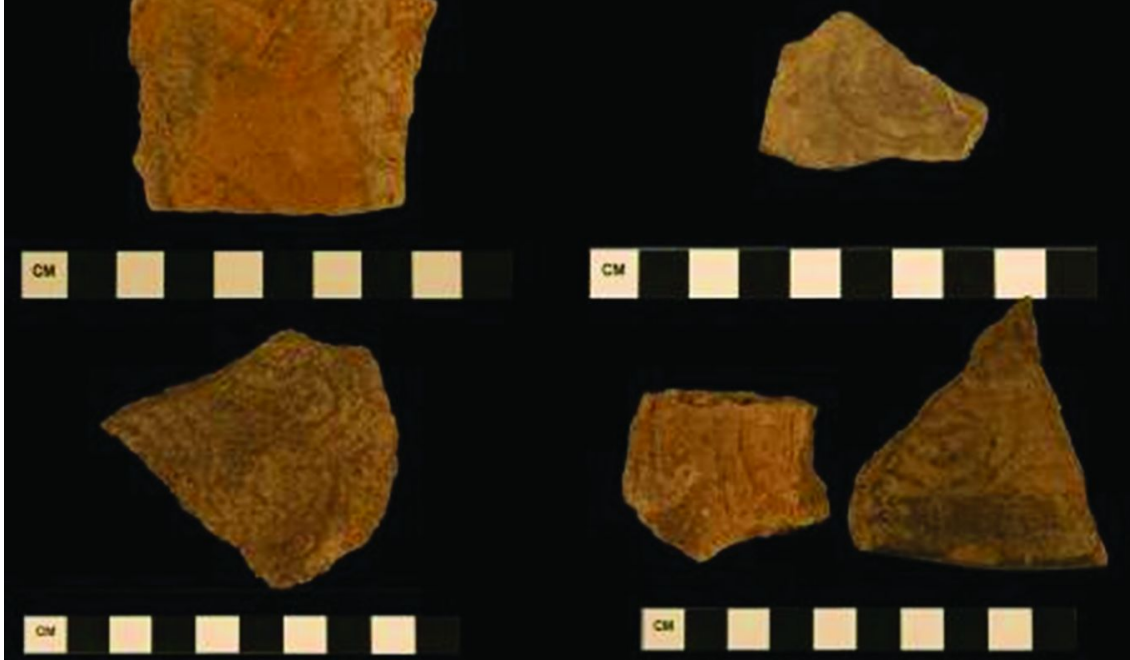

Figure 2. Decorated ceramics from Apalachicola sites in northwest Florida.Top two rows: Fort Walton Incised; bottom two rows: Lamar Complicated-Stamped. Photos courtesy of M. Koppe.

In Archaeological Chemistry VIII; Armitage, R., et al.; ACS Symposium Series; American Chemical Society: Washington, DC, 2013. 

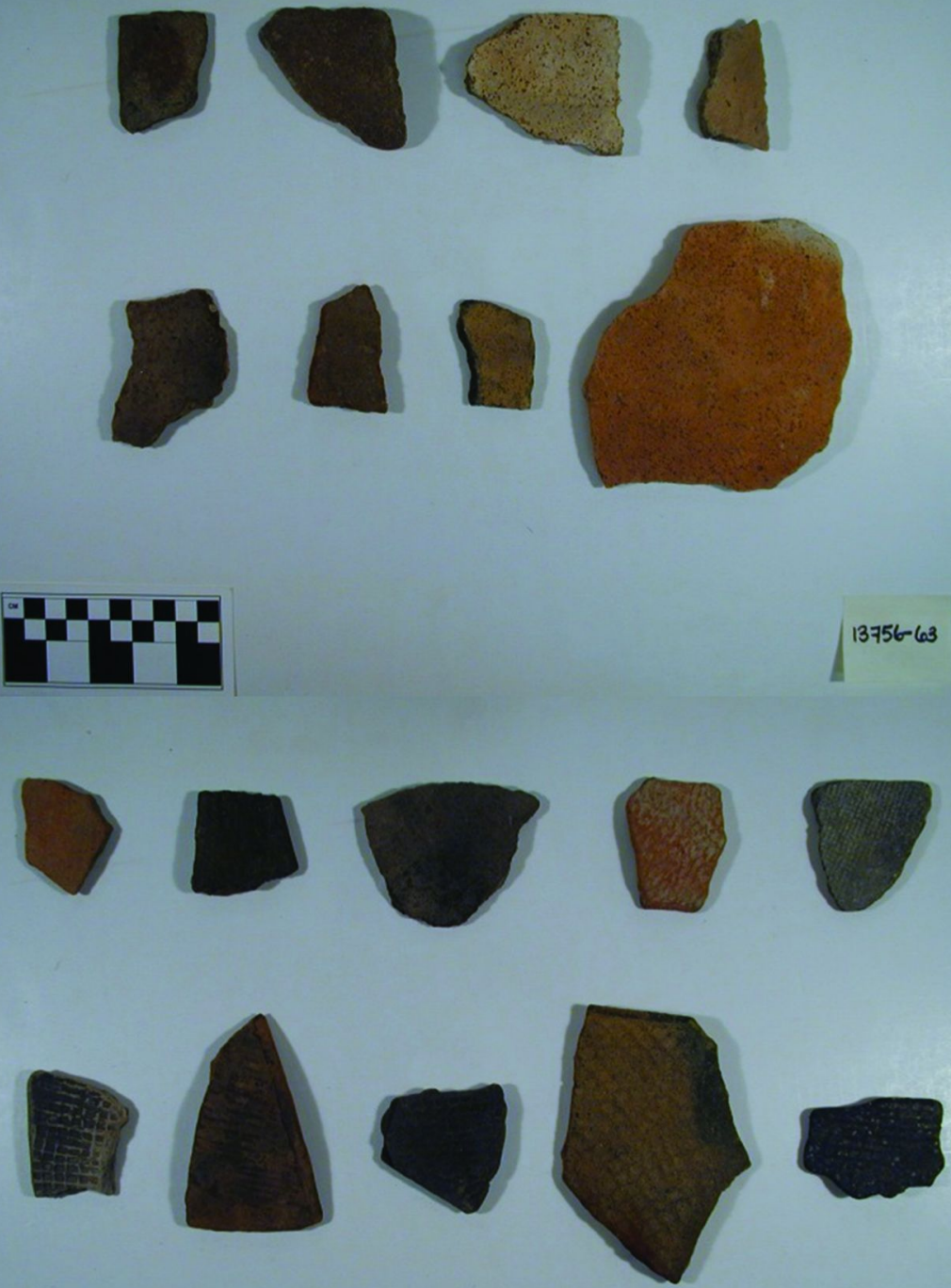

13775- 84

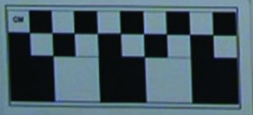

\section{5-84}

Figure 3. Undecorated (top two rows) and decorated (bottom two rows) pottery sherds from the Curlee site. Photos courtesy of M. Koppe.

In Archaeological Chemistry VIII; Armitage, R., et al.;

ACS Symposium Series; American Chemical Society: Washington, DC, 2013. 


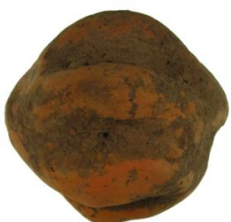

USF 12018

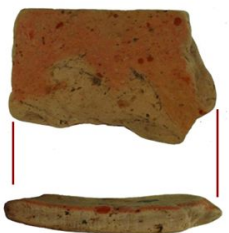

USF 12022

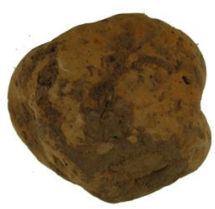

USF 12019

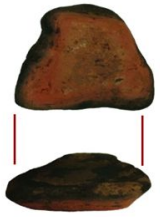

USF 12023

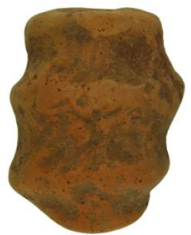

USF 12020

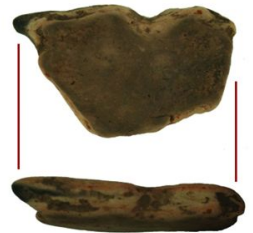

USF 12024

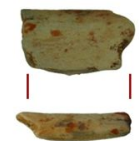

USF 12021

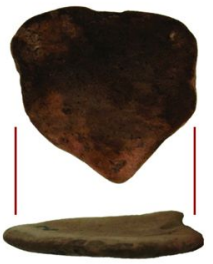

USF 12025

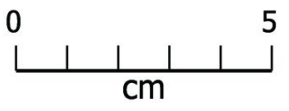

Figure 4. Poverty Point Objects and St. John's pottery sherds from the Archaic site of Poverty Point, Louisiana. Photos courtesy of R. Weinstein.

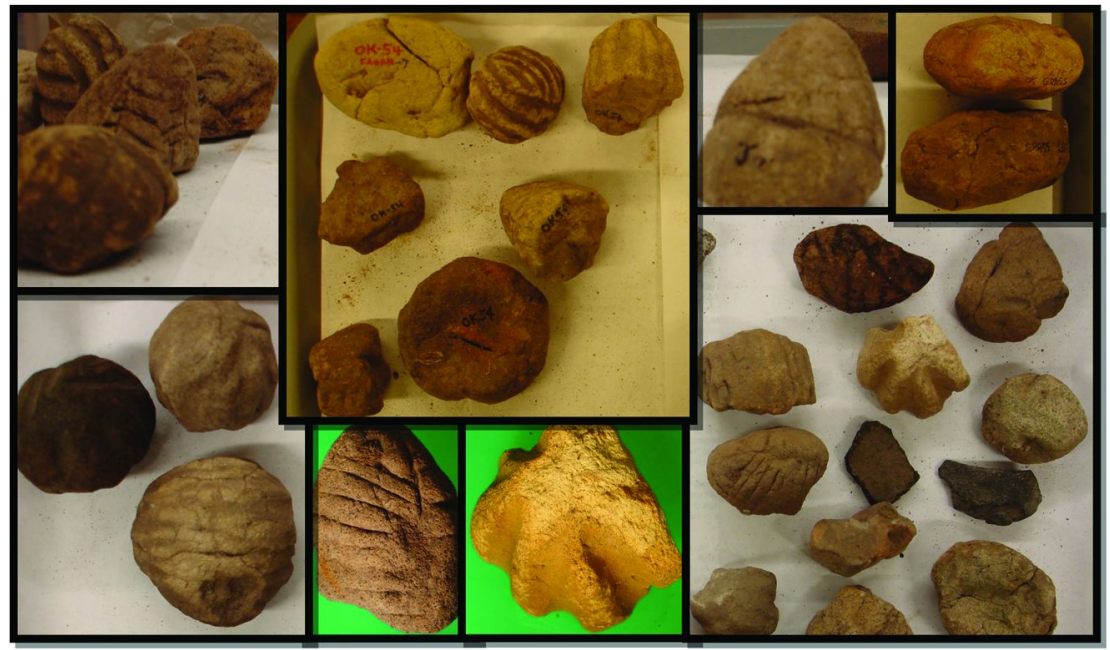

Figure 5. A selection of the Poverty Point-type baked-clay objects in the Choctawatchee Bay private collection. Photos courtesy of D.S. Woodward. 


\section{Elemental Analysis Using pXRF}

$\mathrm{X}$-ray fluorescence spectrometry has been applied to archaeological materials for many decades, and the principles of this method will not be discussed here (see (6)). The use of portable and especially hand-held X-ray fluorescence spectrometers on archaeological materials, however, was very rare until a decade ago, and now has been widely used on obsidian, which is a homogeneous glassy material (e.g. (7-9)). A number of non-destructive studies have also been done on ceramics, with the understanding of their heterogeneity due to clay type and temper added, as well as surface decoration with slip or paint (10-15). The advantages of the pXRF include being non-destructive, the ability to conduct analyses in museums and other locations rather than bringing artifacts back to a laboratory, and to rapidly analyze large numbers of objects, and these aspects are well understood. While only analyzing the surface is technically a disadvantage compared to homogenized powder samples, since the depth of most secondary $\mathrm{X}$-rays is less than $1 \mathrm{~mm}$, the X-ray beam area is about $4 \times 6 \mathrm{~mm}$ and multiple spots may be selected to average and assess variation. The ceramics in this study are also not painted or slipped, so the surface is likely to represent the clay used for the whole object.

There are several commercially produced hand-held pXRF instruments available. Most of the studies represented here were done using a Bruker III-V model, while one site was analyzed using a more recently acquired Bruker III-SD. The latter has greater sensitivity, and was run at 2048 rather than 1024 channels (thus improving resolution and element identification), and for 120 instead of 180 seconds. Analyses were conducted using two different settings: $40 \mathrm{kV} / 10 \mu \mathrm{A}$ with a filter $(6 \mu \mathrm{m} \mathrm{Cu}, 1 \mu \mathrm{m} \mathrm{Ti}, 12 \mu \mathrm{m} \mathrm{Al})$, providing greater sensitivity and precision for $\mathrm{Fe}$ and trace elements $\mathrm{Rb}, \mathrm{Sr}, \mathrm{Y}, \mathrm{Zr}$, and $\mathrm{Nb}$; and $40 \mathrm{kV} / 1.5 \mu \mathrm{A}$ with no filter, for both major element composition of the ceramics ( $\mathrm{Si}, \mathrm{Al}, \mathrm{K}, \mathrm{Ca}, \mathrm{Ti})$ as well as trace elements, but with less sensitivity and precision for the latter. For better assessment of $\mathrm{Si}, \mathrm{Al}, \mathrm{Mg}, \mathrm{K}$, and $\mathrm{Ca}$, we would have used the latter settings with a vacuum and chosen especially flat surfaces to analyze.

The ceramics were well-cleaned, and analyses conducted on both inner and outer surfaces and occasionally on edges to check for variability in the data produced. The pXRF was positioned upright on a plastic stand with the samples balanced on top. The beam area analyzed is greater than what is typically analyzed by laser ablation ICP-MS, and the combination of spots tested makes this approach similar to INAA and regular XRF studies without being destructive. The calibration software program corrects for analyzing edges that do not cover the entire beam area.

\section{Data Analysis}

The raw data were calibrated using software aimed at silicon-based materials and is based on many standards tested by INAA, ED-XRF, and ICP-MS. More than 80 pottery sherds also were tested using both Bruker III-V and III-SD pXRF instruments and a linear equation developed to re-calibrate the data from the older instrument. A direct comparison of the multiple spots tested for each sherd 
was made to check for heterogeneity, before taking the average to represent the sample. A preliminary $\mathrm{X}-\mathrm{Y}$ graph of $\mathrm{Zr} / \mathrm{Sr}$ vs. $\mathrm{Rb} / \mathrm{Sr}$ illustrated measurable compositional differences within this one area of northwest Florida, and therefore the capability of analyses with the pXRF to address archaeological questions about ceramic production and trade.

Principal components analysis, using trace element data for $\mathrm{Rb}, \mathrm{Sr}, \mathrm{Y}, \mathrm{Zr}$, and $\mathrm{Nb}$ for the PPO-style objects from the Late Archaic sites in Choctawhatchee Bay and at Clark Creek, show that most fall in a separate group from the other sites tested in the Apalachicola River area. The clay-ball sample from Clark Creek, however, is an excellent match with those from Poverty Point, while one from Choctawatchee Bay may have come from that region (Figure 6). Along with the Tick Island artifacts previously tested, these results support the hypothesis of small-scale, long-distance ceramic exchange between northern Florida and Louisiana.

PCA for three of the later period Apalachicola River sites tested (Curlee, Depot Creek, Otis Hare) suggests multiple clay sources near each site were commonly used - hence the range of values for each site's assemblage - but that there were differences in the sources typically used for each site that may be distinguished (Figure 7). Other clay sources were likely located between the archaeological sites so that there was movement of pottery over short distances and/or access to the same source by sites producing pottery. The vast majority of pottery seems to have been produced from local clay sources. Modest variation within a site-based group is best interpreted as the use of multiple clay outcrops in the neighborhood of each archaeological site.

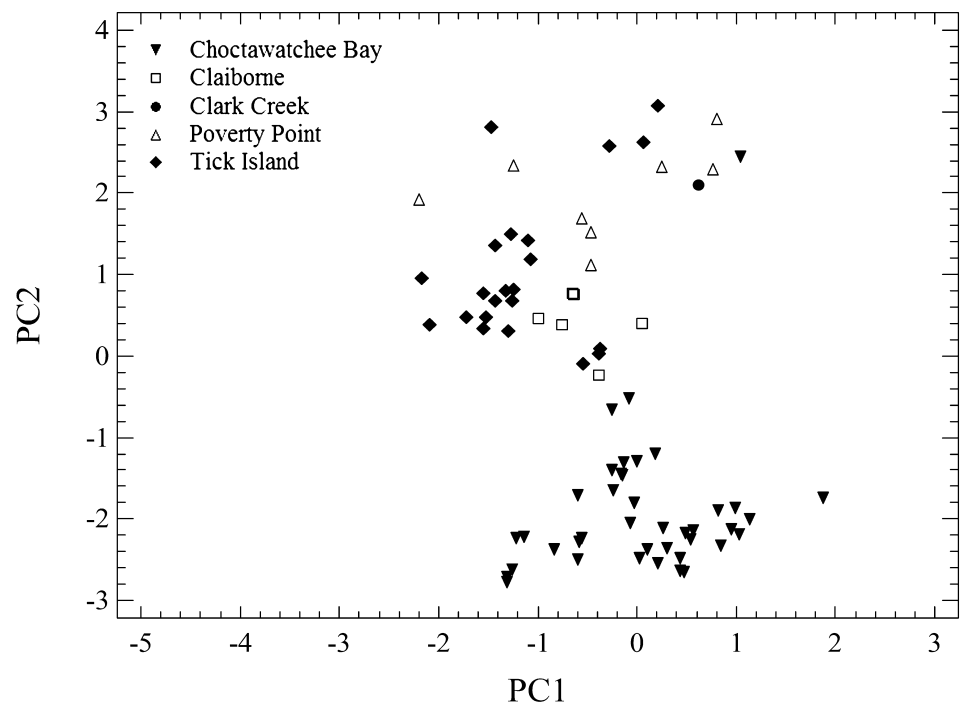

Figure 6. Principle components analysis of trace elements $\mathrm{Rb}, \mathrm{Sr}, \mathrm{Y}, \mathrm{Zr}, \mathrm{Nb}$ matches a clay ball from Clark Creek (FL) with Poverty Point (LA). 


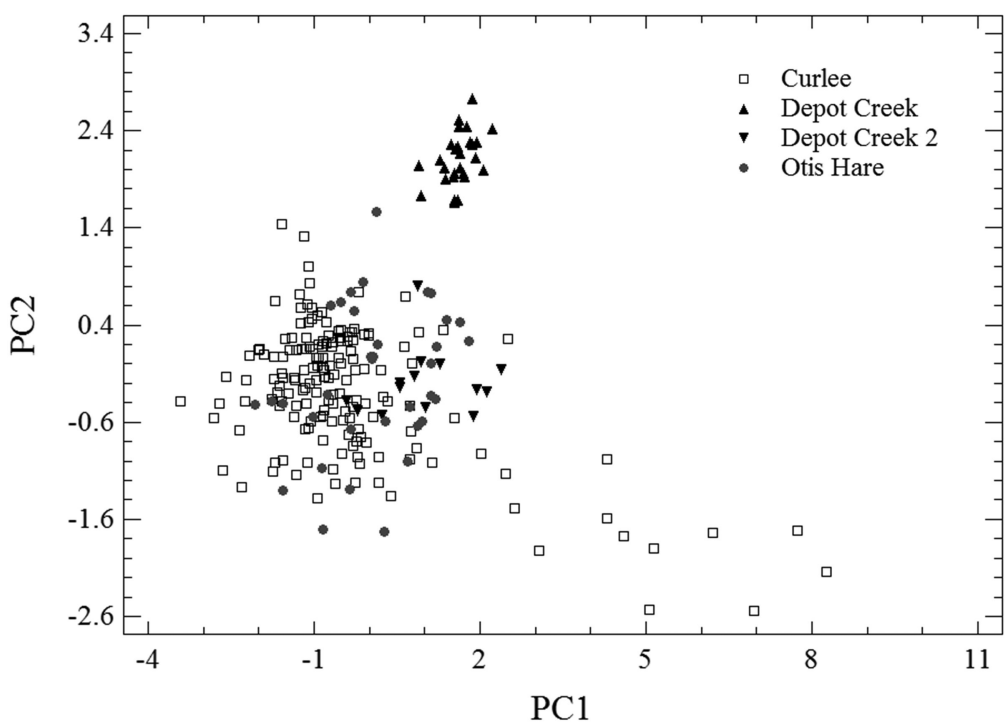

Figure 7. Principle components analysis of trace elements reveals differences in clay composition between sites in the Apalachicola River area.

\section{Discussion and Future Work}

Analysis by pXRF of ceramics in northwest Florida and elsewhere is clearly useful for studies of trade and contact. In northwest Florida it appears that there were at least occasional cultural connections with other areas of the southeastern United States, in the Late Archaic period as well as in the Mississippian and early-contact Fort Walton periods (16). Ideally, clay sources near the sites of interest should be identified, and samples tested, for much clearer interpretation of the archaeological ceramic analytical data. Analysis of large numbers of selected ceramic artifacts could also be done to assess whether there are patterns based on specific pottery types or decoration.

The ability to conduct such non-destructive and rapid analyses, on both potsherds and full-size vessels, within museums and material depositories, provides large datasets that enable strong hypothesis testing. While only a surface analysis on potentially heterogeneous potsherds, the relatively wide beam size and ability to analyze multiple spots largely removes this issue when compared with powdered homogenized samples from one spot. Of course, surface analysis on painted or glazed ceramics will not reflect the composition of the clay, but edges of a sherd may be analyzed.

Further work is needed however in the development of calibration software for archaeological materials being tested with $\mathrm{pXRF}$ spectrometers, especially in order to compare data between laboratories and other kinds of instruments (17). For most major elements ( $\mathrm{Si}, \mathrm{Al}, \mathrm{K}, \mathrm{Mg}, \mathrm{Na})$, their secondary X-rays are largely absorbed in the air, so in order to have even a semi-quantitative measurement it is necessary to use an attachable vacuum and to have a flat surface on the artifact (18). Especially when no ceramic thin-sections are taken and studied to identify 
the overall clay type, analysis of major elements is necessary. The detection limits of the pXRF spectrometer will not allow measurements of elements in the low ppm or high ppb range that are detected by INAA and other instruments, so that some compositional groups identified using pXRF data may actually represent multiple subgroups, especially if based on just a small number of elements. As with many other scientific methods of analysis, practitioners, collection managers, and data consumers need to be educated as to the advantages and disadvantages of pXRF for archaeological materials.

\section{Acknowledgments}

We appreciate the opportunity provided by excavators and collectors of surface finds to conduct these analyses. Many students participated in this research, including USF undergraduates K. Cogswell, S. Parker, A. Robinson, and L. Rosado who conducted some of these analyses as a class project. We also thank the USF Honors College for their financial support.

\section{References}

1. Du Vernay, J. P. Ph.D. Dissertation, University of South Florida, Tampa, FL, 2011.

2. Koppe, M. M.A. Thesis, Université Michel de Montaigne Bordeaux 3, France, 2010.

3. Woodward, D. S. M.A. Thesis, University of South Florida, Tampa, FL, 2012.

4. Wallis, N. J.; Boulanger, M. T.; Ferguson, J. R.; Glascock, M. J. Archaeol. Sci. 2000, 37, 2598-2611.

5. Hays, C. T.; Tykot, R. H.; Weinstein, R. A. 66th Annual Meeting of the Southeastern Archaeological Conference, Mobile, AL, November 4-7, 2009.

6. Shackley, M. S. X-Ray Fluorescence Spectrometry (XRF) in Geoarchaeology; Springer: New York, 2010.

7. Craig, N.; Speakman, R. J.; Popelka-Filcoff, R. S.; Glascock, M. D.; Robertson, J. D.; Shackley, M. S.; Aldenderfer, M. S. J. Archaeol. Sci. 2007, 34, 2012-2024.

8. Shackley, M. S. SAA Archaeol. Record 2010, 10 (5), 17-20, 44.

9. Tykot, R. H.; Lai, L.; Tozzi, C. In Proceedings of the 37th International Symposium on Archaeometry, May 13-16, 2008, Siena, Italy; TurbantiMemmi, I., Ed.; Springer: New York, 2011; pp 321-328.

10. Burley, D. V.; Dickinson, W. R. J. Archaeol. Sci. 2010, 37, 1020-1026.

11. Goren, Y.; Mommsen, H.; Klinger, J. J. Archaeol. Sci. 2011, 38, 684-696.

12. Matsunaga, J. M. Soc. Archaeol. Sci. Bull. 2009, 32 (4), 8-12.

13. Morgenstein, M.; Redmount, C. A. J. Archaeol. Sci. 2005, 32, 1613-23.

14. Speakman, R. J.; Little, N. C.; Creel, D.; Miller, M. R.; Iñañez, J. G. J. Archaeol. Sci. 2011, 38, 3483-3496.

15. McCormick, D. R. M.A. Thesis, University of South Florida, Tampa, FL, 2013.

16. Marrinan, R. A.; White, N. M. Southeastern Archaeol. 2007, 26, 292-318. 
17. Aimers, J. J.; Farthing, D. J.; Shugar, A. N. In Handheld XRF for Art and Archaeology; Shugar, A. N., Mass, J. L., Eds.; Studies in Archaeological Sciences 3; Leuven University Press: Belgium; pp 423-448.

18. Johnson, J. J. Archaeol. Method Theory 2012, October 17, 1-26, DOI: 10.1007/s10816-012-9162-3. 